\title{
The effect of the core/shell nanostructure arrays on PEM fuel cells: a short review
}

\begin{abstract}
Fuel cell technology is one of the solutions which can play an important role in the environmentally friendly with more efficient, cleaner and quieter than traditional internal combustion engines. Among the fuel cells types polymer electrolyte membrane fuel cells have many advantages regarding quick start-up time, less warm-up time high power density and high efficiency. There are still some limitations due to the cost of Pt-based catalysts. Platinum based catalysts are presently the most promising catalysts for Oxygen Reduction Reaction (ORR) in Fuel Cells. Homogenously distributed Pt nanoparticles on carbon support $(\mathrm{Pt} / \mathrm{C})$ nanoparticles are mostly using in conventional way to produce Fuel Cells. Pt-based electrocatalysts with higher activity and durability are needed for cost-competitive PEM Fuel Cells. It can be developed/improved further by using Platinum-based/alloy thin film core-shell nanostructures. For this reason, this article reviewed the significance and processing of such core/shell structures. The general information about Fuel Cells is given at the beginning of this review article. Later, type of the fuel cells along with more definition of the PEM Fuel Cells are described. The Pt shell on Ni, Cr, Pd, Ru, and WC core nanorods increase the stability and durability and decrease the cost based on the published works. This nanostructured design will significantly impact the fuel cell technology by improving catalysts. Specifically, by controlling size, composition, and surface-area-to-volume ratios, this review article describes the investigation of the core/shell nanostructured array catalysts. A few of the following examples of core/shell structures and supported catalysts proved electrocatalytic oxygen reduction.
\end{abstract}

Volume 2 Issue 2 - 2018

\section{Mesut Yurukcu,' Emad O Badradeen,' Shelbey Bilnoski,' Fatma MYurtsever, ${ }^{2}$ Mahbuba Begum'}

'Department of Physics and Astronomy, University of Arkansas at Little Rock, USA

${ }^{2}$ Department of Chemistry, University of Arkansas at Little Rock, USA

Correspondence: Mesut Yurukcu, Department of Physics and Astronomy, University of Arkansas at Little Rock, Little Rock, AR, 72204, USA, Email mxyurukcu@ualr.edu

Received: February 25, 2018| Published: April 24, 2018

\section{Introduction}

\section{Fuel cells}

There are two compelling reasons that interest in development of fuel cells is increasing: the primary reason being that fossil fuels are being depleted. Alternative energy-source-development is vital if modern society is to be sustained. The secondary-yet perhaps more significant-reason is that fossil fuels are not a clean source of energy; they are hazardous for the environment. The burning of fossil fuels pollutes the air, water, and ground which humanity depends on for life thus endangering global health. Fuel cells that utilize hydrogen are an important energy source for the future. Both highly efficient and environmentally friendly, fuel cells are the cleanest and most energyefficient technology presently being developed. Imagine stacking enough fuel cells to power a vehicle and having the only by-product of waste being water!

One of the biggest perpetuators of fossil fuel combustion is the auto industry. Much environmental pollution can be attributed to the use of fossil fuels to power automobiles. Because this is the case, this industry also is one of the biggest financial contributors to fuel cell research and development. ${ }^{1}$ While the need for cleaner energy partially motivates the industry's financial contribution, this is not the most pressing motivator: the more fossil fuels are depleted the higher prices are driven up. ${ }^{2}$ However, it cannot be ignored that the $\mathrm{CO}_{2} \mathrm{NO}_{2}$, and volatile-organic-compound emissions from automobiles into the atmosphere is only beneficial to the automobile industry. ${ }^{3}$ While those in the industry reap financial gain, the ecosystems reap damaging effects, humans reap respiratory illnesses, and the atmosphere reaps more "green gas" which optimizes the effects of global warming. In lieu of these facts, inevitably viable alternative energy sources such as fuel cells technology must be explored. The research and development for cleaner energy must be financially backed. A replacement energy form must be established and implemented; the future of the world depends on it.

Several decades have passed since the initial discovery of fuel cells by German scientist Christian Friedrich Schoenbein in $1838,{ }^{4}$ but despite this he is not referred to as the, "Father of the Fuel Cell." This title belongs to Sir William Grove who in 1839 proved that it is possible to generate electricity through the reverse electrolysis of water. ${ }^{5}$ Building on Grove's discovery, in 1889, Charles Larger and Ludwing Mord first coined the phrase, "fuel cell," while further refining Sir William Grove's original work four decades after Schoenbein's 1838 discovery. ${ }^{6}$ Since then, many researchers have embarked to further develop this discovery to harness the potential clean energy source. In 1932, Francis Bacon engineered the first functional fuel cell; and two decades later, in 1950, his idea was commercialized by General Electric. General Electric created the first Polymer Electrolyte Membrane (PEM) fuel cell. Between this commercialization and 1966, the US Navy and NASA optimized on the emerging energy source and engineered several types of fuel cell electric cars. Now, since 2005, fuel cell cars have been made available to the general public via Honda, Toyota, and Hyundai. ${ }^{6-9}$

A fuel cell is an electrochemical device like a battery that converts chemical energy into electrical energy by using an external fuel $\left(\mathrm{H}_{2}\right.$, methanol, etc. $)$ and an oxygen supply. ${ }^{10-12}$ Fuel cells are promising power generation devices that have high efficiency and low environmental impact. Every fuel cell has two electrodes called the anode and cathode. The oxygen from air reacts at the cathode side, and hydrogen or hydrocarbon fuel reacts at the anode side. The output is direct current electrical energy. When hydrogen is used as fuel, the final product is simply water..$^{13-16,17}$ Besides the anode and cathode side, each fuel cell consists of gas-flow structures which supply air 
and fuel flow to the electrodes and separators which divide each cell while conducting electrons. ${ }^{16}$ These electrochemical reactions that occur in the fuel cells are heterogeneous surface reactions; thus, the higher the surface-area-to-volume ratio, the higher the reaction rates. If the electrode kinetics is sluggish, this is addressed by catalysts supported on the electrode surfaces. Traditionally platinum (Pt) is used as a catalyst in practically all fuel cells, but the cost can be minimized by sparingly using the platinum and dispersing other catalysts as well as nanostructures. This article discusses developing active and robust catalysts to disperse in addition to the-Pt catalyst nanostructures. This method is currently a key area of research in the field of fuel cell technology. Focusing on nanotechnology as a guide for catalyst research and development, this article discusses how this field of study is progressing.

\section{Types of fuel cells}

Today, there are many fuel cell types that represent distinct technologies that require unique material solutions. The long-term reliability of the fuel cells significantly affects the economics and commercialization of the technology. ${ }^{1,16-21}$

It is conceived and anticipated that all fuel cell types listed in Figure 1 will find many applications. Major types of hydrogen-oxygen fuel cells broadly developed since about 1960 are listed as follows: ${ }^{21,22}$

a. Direct Methanol Fuel Cells (DM FCs). The working temperatures are between $50^{\circ} \mathrm{C}$ to $120^{\circ} \mathrm{C}$.

b. Membrane-type Fuel Cells (PEM FCs). The electrolyte has a polymeric ion-exchange membrane; the working temperatures are $\sim 80^{\circ} \mathrm{C}$.

c. Alkaline Fuel Cells (A FCs). The electrolyte is $40 \%$ to $70 \% \mathrm{KOH}$ and the working temperatures are between $90^{\circ} \mathrm{C}$ and $100^{\circ} \mathrm{C}$. Such systems were used on United States space shuttles.

d. Phosphoric Acid Fuel Cells (PA FCs). The electrolyte is $85 \%$ to $95 \%$ phosphoric acid; the working temperatures are between $100^{\circ} \mathrm{C}$ and $250^{\circ} \mathrm{C}$. Such systems were used to build numerous autonomous power plants with outputs of up about $250 \mathrm{~kW}$.

e. Molten-Carbonate Fuel Cells (MC FCs). The electrolyte is a molten mixture of carbonates of sodium, potassium, and lithium; the working temperatures are between $600^{\circ} \mathrm{C}$ and $700^{\circ} \mathrm{C}$. Experimental plants with a power of up to $0.5 \mathrm{MW}$ have been built with such systems.

f. Solid Oxide Fuel Cells (SO FCs). The working electrolyte is a solid electrolyte based on zirconium dioxide doped with oxides of yttrium and other metals; the working temperatures are between $700^{\circ} \mathrm{C}$ and $1000^{\circ} \mathrm{C}$. Experimental plants with a power of up to $100 \mathrm{~kW}$ have been built with such systems in the United States and Japan (Figure 2).

Proton exchange membrane fuel cells (PEM FCs) have advantageous features as compared to other varieties: low-operating temperatures $\left(\sim 80^{\circ} \mathrm{C}\right)$, sustained operation at high-current densities, compactness, low weights, low costs and volumes, long stack life, fast start-ups, and thus suitability for automotive applications where quick startups are required. ${ }^{23}$

\section{Polymer electrolyte membrane fuel cells}

Polymer electrolyte membrane fuel cells (PEM FCs) are likely to be the dominant technology of the next era because of their afore mentioned advantages. ${ }^{13,14,24-29}$ Hydrogen gas is one of the key components of PEM fuel cells. ${ }^{30}$ Figure 3 shows a schematic of a PEM fuel cell. The thin porous anode and cathode are combined with the electrolyte membrane which is a solid organic polymer, and the formed composites are called membrane electrode assembly (MEA). The polymer electrolyte consists of a perfluorinated polymer backbone with sulfonic acid side chains and is an excellent proton conductor when fully humidified. ${ }^{31}$ The MEA consists of a proton exchange membrane, catalyst layers, and gas diffusion layers (GDL). ${ }^{31-33}$ The oxygen and hydrogen gas reactants are fed into a gas-diffusion layer(GDL)- that is in close contact with the porous electrodes of the anode and cathode.

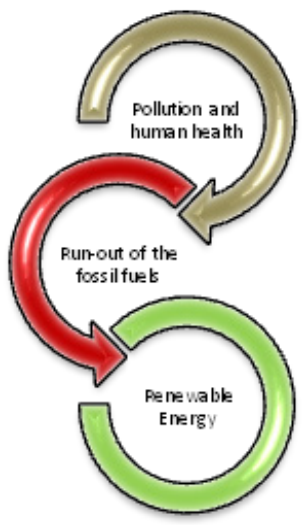

Figure I Two major driving forces for the increasing interests in the development of fuel cells.

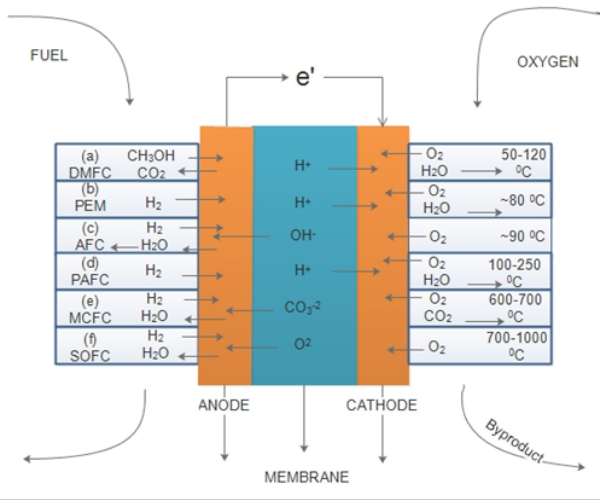

Figure 2 Various fuel cell types from top to bottom; (A) Direct Methanol Fuel Cells (DM FCs), (B) Polymer Electrolyte Membrane Fuel Cells (PEM FCs), (C) Alkaline Fuel Cells (A FCs), (D) Phosphoric Acid Fuel Cells (PA FCs), (E) Molten Carbonate Fuel Cells (MC FCs), (F) Solid Oxide Fuel Cell (SO FCs). . $^{21,22}$

In a process known as the hydrogen oxidation reaction (HOR), hydrogen is fed to the anode side where the catalyst encourages the hydrogen atoms to release electrons and become hydrogen ions (protons). Hydrogen is then oxidized into protons and electrons according to equation (1). The electrons travel in the form of an electric current that is used before it reaches to the cathode side of the fuel cell where oxygen originated. At the same time, the protons diffuse through the membrane to the cathode where the hydrogen atom undergoes a chemical reaction with oxygen to produce water. This process is called the oxygen reduction reaction (ORR) according to equation (2). The overall reaction is exothermic and can be written 
as equation (3). ${ }^{30-35}$ As a summary, the PEM fuel cell reactions are as follows:

$$
\begin{aligned}
& \text { Anode: } 2 \mathrm{H}_{2} \rightarrow 4 \mathrm{H}^{+}+4 e^{-} E^{0}=0 \mathrm{~V} \\
& \text { Cathode: } \mathrm{O}_{2}+4 \mathrm{H}^{+}+4 e^{-} \rightarrow 2 \mathrm{H}_{2} \mathrm{O} \quad E^{0}=1.23 \mathrm{~V} \\
& \text { Overall: } 2 \mathrm{H}_{2}+\mathrm{O}_{2} \rightarrow 2 \mathrm{H}_{2} \mathrm{O} \quad E^{0}=1.23 \mathrm{~V}
\end{aligned}
$$

Water and heat are the only by-products of these reactions. Direct chemical combustion is prevented by the electrolyte that separates the fuel $\left(\mathrm{H}_{2}\right)$ from the oxidant $\left(\mathrm{O}_{2}\right)$. The electrolyte serves as a barrier to gas diffusion, only allowing protons to cross over. ${ }^{33}$ While PEM fuel cells have moved towards commercialization for various markets, there are still limitations that need improvements such as performance, durability, and cost. ${ }^{36}$

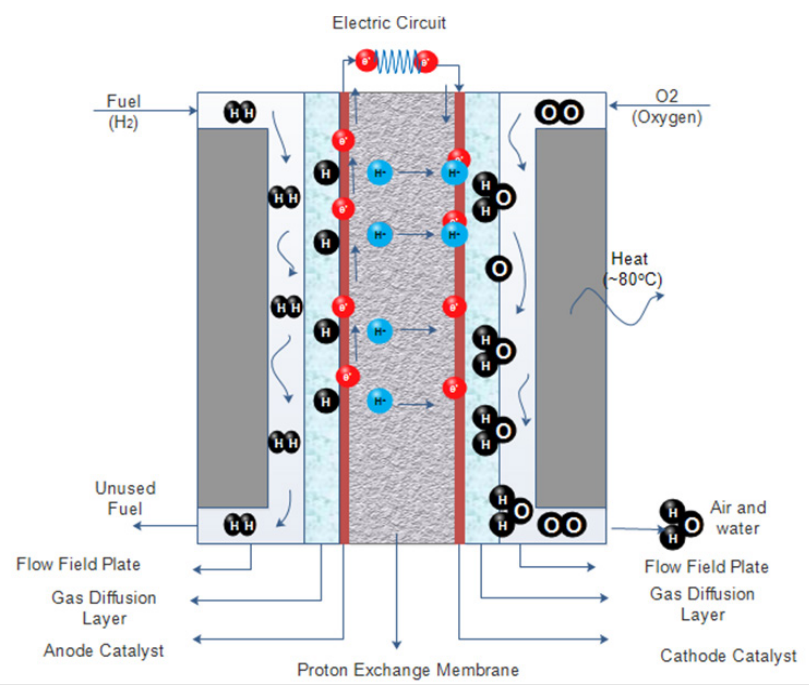

Figure 3 Schematic of a PEM fuel cell.

\section{Limitations of traditional PEM fuel cell electrodes}

As discussed in brevity earlier in this article, though quite costly, $\mathrm{Pt}$ is required as a catalyst by all Polymer electrolyte-based PEM fuel cells. Much of fuel cell technology research has revolved around attempting to engineer less expensive nanomaterial alternatives to platinum. This intensive effort has been in effect for over a century to no avail; ;0,37,38 no better material has been found. Being costlier than gold, Pt is a precious and stately resource. The atomic weight and number of Pt are 195.08 amu and 78, respectively. The ORR above in equation (2) pivots on the face-centered-cubic (FCC) crystal structure in the fuel cell being specifically oriented to facilitate this reaction. Since different variations of orientation of FCC in electrolyte liquids in relation to ORR activity has been studied, presently Pt metal forms a FCC crystal structure that results in surficial 111, 100, and 110 crystal planes. ${ }^{39-41}$ The ORR activity is too dependent on the orientation of the FCC of the electrode material in electrolyte solution; this limits the availability of material options for the electrode material. Unfortunately, present day efforts to reduce the use of Pt consistently result in less-effective, sluggish fuel cell ORR rates, especially when compared to the rate of the HOR.

Conventional PEM fuel cell electrodes consist of layers of Pt catalyst nanoparticles (3-5 $\mathrm{nm}$ in size) supported on carbon nanoparticles. An ionomer (solution form of the membrane polymer) infiltrates through this network of nanoparticles (Figure 4). This type of fuel-cell electrode architecture suffers from several important limitations: $:^{25-27}$

i. The ORR at the cathode is a sluggish reaction; this typically is major contributor to the efficiency loss in an operating PEM fuel cell. Pt loadings may reach as high as $0.6 \mathrm{mg} / \mathrm{cm}^{2}$ at the cathode side. In the case of hydrogen fuel cells, compared to ORR, the HOR at the anode is very fast.

ii. Pt nanoparticles tend to agglomerate into larger clusters or dissolve into the electrolyte due to the small size effect resulting from the catalyst surfaces' area losses. Generally, a precious metal catalyst such as platinum may be considered stable, but it is not always stable at high temperature, high voltages, or in oxygen rich atmosphere when the size is reduced to the "nano" scale. $^{30}$

iii. Although the oxidation of carbon is not recognized as a significant problem under well-controlled operating conditions, it is a significant problem during fuel cell start-up, shut-down and under fuel starvation conditions. ${ }^{42}$ Oxidation of carbon supports causes the catalyst loss. ${ }^{43}$

iv. Carbon supports facilitate peroxide species' formation that leads to degradation of the membrane polymer. ${ }^{44}$

v. Carbon separates over time from the ionomer (i.e. solution form of the membrane polymer that enhances the conduction of protons from/to the catalyst nanoparticles) leading to decrease in effectiveness. ${ }^{43}$

vi. Catalyst-support thermal stability is particularly poor at elevated temperatures.

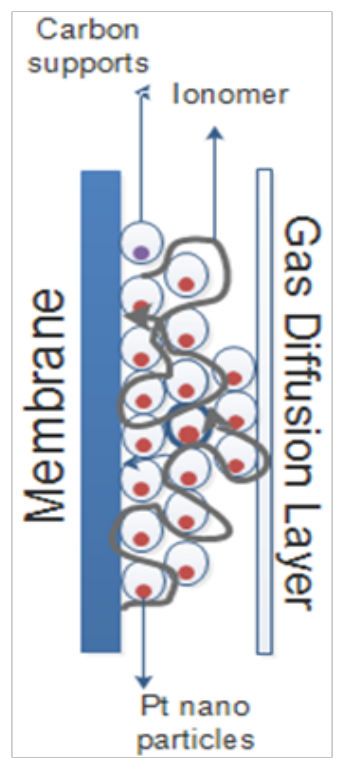

Figure 4 Conventional electrode design for PEM fuel cells. ${ }^{45}$

Because of these aforementioned issues, fuel cell research strives to develop an alternative support material, a carbon-free electrocatalyst, that is more durable and more cost-effective ${ }^{45-47}$ Through controlling the roughness factor-that is the ratio of the active surface area to the geometric surface area, promoting single-crystal property, and optimizing FCC orientation, the electrochemical activity of PEM fuel cells can potentially be enhanced. ${ }^{44-53}$ An additional cause for loss in 
efficiency in operating PEM FCs are cathode catalyst layers. The issue is that utilizing optimally the catalyst material accounts for a large fraction of the overall cost of the fuel cell system. Today, the most suitable catalyst for enduring operation conditions in PEM FCs is Pt. ${ }^{54}$ A critical barrier in dissemination of PEM FCs is extreme dependence on Pt as both anode and cathode electrocatalysts. Pt has excellent electrochemical performance and high stability, but it is expensive, and the supply is limited. There are several promising alternative materials recently reported as cathode catalysts for oxygen reduction. However, researchers are still working on designing a fuel cell with reduced use of $\mathrm{Pt}$ but decreased limitations and issues. ${ }^{50-52,55}$

The Department of Energy (DOE) is the primary authority that outlines future goals for fuel cell development-especially PEM FCs. The DOE's targets for 2020 are, " $14 \$ / \mathrm{kWnet}, 5000$ hours of durability with cycling, $300 \mathrm{~mA} / \mathrm{cm}^{2}$ performance at $0.8 \mathrm{~V}, 1000$ $\mathrm{mW} / \mathrm{cm}^{2}$ performance at rated power; $20 \$ / \mathrm{m}^{2}$ cost, $0.125 \mathrm{mg} / \mathrm{cm}^{2}, \mathrm{~g}$ $\mathrm{kW}$ electrode for [Pt] PEM total loading (both electrodes) less than $40 \%$ loss in mass activity. ${ }^{56}$ Aside from the cost of the precious metal, another major problem with this method is the core/shell structure's durability; this problem makes the inclusion of Pt vital. Due to the loss of nanorods during fuel cell operations, the uncoated core nanorods can have durability issues stemming from what materials they are made from. These problems can be greatly reduced by coating the nanorods with durable materials like Pt. To make catalysts with both durability and activity at a low cost, innovation of present concepts and strategies are necessary. New methods to effectively and efficiently compose and morph multi-metallic nanostructure catalysts must be discovered and developed. There are many variances between "nano" scale structures and their bulk structures like differing leach away times dependent on coating of core/shell structures and varying atomic-metallic transitions. Developing a thorough understanding of why these distinctions exist and how they relate between materials at the "nano" and bulk scales is necessary to further pioneer the commercialization of this technology, also crucial to further expanding fuel cells' horizon understands how catalytic activity and stability differ from the "nano" to the bulk scales. A good start to understanding these differences is studying morphology, porosity, and composition of the materials. ${ }^{45}$ The core/shell structures produced durability is further increased when the nanorods are coated in a conformal fashion; this is the fashion in which the process has been done for this work.

How to prepare Pt-group catalysts - especially Pt alloyed with other less precious metals - for optimal reactions has been a key focus of fuel cell research. ${ }^{48,50,52}$ Thermal evaporation and thin-film sputtering depositions have been two traditional methods used to prepare supported nanostructure catalysts. These approaches have been liberally used in order to prepare metal catalysts on support materials. While these two traditional methods have been prepared for various supported Pt-group binary, secondary, or ternary catalysts, ${ }^{26,55,58-61}$ they are limited in ability to control composition and size due to scaling differences between the bulk and "nano" material structures. Core/ shell type nanomaterials have been of rising interest in the modern age because these materials successfully overcome some challenges of nanoscale particle preparation. Core/shell nanomaterials consist of two separate matters closely interacting. However, aggregation of nanoparticles eventually leads to loss of catalytic activity in nanoscale practical applications. This nanostructured design will significantly impact fuel cell technology by improving catalysts preparations while simultaneously being more cost-effective. ${ }^{18,62}$
Core/shell nanostructures will allow for further control of size, shape, and composition at such a precise scale that it will perhaps lead to improvement of current or discovery of new catalytic properties.

Unlike the traditional methods for preparation of supported catalysts, core/shell multi-metallic catalysts' preparation invokes three methods: first, Pt-based nanorods; second, Pt-only-coated shell structures; and finally, Pt-and-other-metals-coated shell with a core of non-Pt metals. To optimize on cost-effectiveness, Glancing Angle Deposition (GLAD) Ni, WC, Cr were used as a catalyst support coated conformally with a Pt thin-film deposited at a small angle deposition (SAD). This GLAD method optimizes reactant flow-especially for high-current density operation-by combining both thin-film electrodes and high-porosity electrodes ${ }^{55,57-64}$ The Khudhayer, WJ et al. ${ }^{64}$ represented a work about vertically-aligned Pt nanorods that were evaluated utilizing cyclic voltammetry $(\mathrm{CV})$ and rotating-disk electrode (RDE) techniques. The Pt core nanorods were prepared by using GLAD methods without any carbon support for various lengths. The size of the Pt-only core nanorods had a maximum of $400 \mathrm{~nm}$ corresponding to $0.32 \mathrm{mg} / \mathrm{cm}^{2} \mathrm{Pt}$ loadings with a diameter and spacing values of less than $100 \mathrm{~nm}$. Their result showed that the nanorods exhibit enhanced stability against loss of electrochemically-active surface area resulting from potential cycling when in acidic electrode as compared to the $\mathrm{Pt} / \mathrm{C}$ nanoparticles' catalyst. However, these Pt core nanorods showed lower mass specific activity due to the large amount of Pt loading compared to the shell coating. Hydrogen production and delivery is critical to successful fuel cell operation. Seongyul K et al., ${ }^{65}$ showed that the increased active area of the nanostructured electrode serves to reduce the operating current density of the electrolyzer. This causes the over-potential to show a corresponding decrease. Developing thin-films of high-active and stable catalysts coated on vertically aligned nanorod arrays of conductive and stable support is the main strategy of these core/shell nanostructures. Kariuki NN et al., ${ }^{52}$ worked on vertically aligned catalysts comprised of platinumnickel (Pt-Ni) thin-films on core nickel (Ni) nanorods with varying ratios of Pt to Ni in the shell thin-films. The Pt-Ni@Ni-Nanorod(NR) catalysts showed superior area-specific and mass activities for ORR compared to those of conventional large-surface area Pt nanoparticle catalysts. Core material is a support material for the core/shell nanorod structures. Begum $\mathrm{M}$ et al., ${ }^{50}$ used tungsten carbide (WC) based nanorods instead of Ni base core structures. They fabricated WC nanorods as support and coated them with a Pt-Ni alloy shell denoted as Pt-Ni@WC catalyst. The Pt-Ni@WC nanostructure rods showed good results compared to conventional nanoparticle structures. Takimoto D, et al. ${ }^{66}$ synthesized the Ru core@Pt shell structures with a series of novel nanosheet catalysts. Their results showed that Ru@ Pt core/shell nanostructures with thickness of 1.5-4.5 Pt monolayers' electrochemical active surface area are larger more than 1.4 compared to typical $\mathrm{Pt} / \mathrm{C}$ catalysts. Jiang $\mathrm{R}$ et al., ${ }^{67}$ explained the core/shell electrocatalysts which have advanced nanostructures have shown notable activity and stability in PEM Fuel Cells. Moreover, Yang L et al., ${ }^{68}$ mentioned that $\mathrm{Pt}$ monolayer catalysts on core structures exhibit at least 4-8 times higher mass activity compared to $\mathrm{Pt} / \mathrm{C}$ catalysts. In recently, Dhanasekaran $\mathrm{P}$ et al. ${ }^{69}$ studied on using three conventional three electrode setup that showed that Pt shell on Carbon coated Titania nanorods more durable, $48 \%$ of initial electrochemical surface area of catalyst remain on the surface than conventional Pt on carbon particles. Carbon Nano Tube(CNT) used as a core material and coated with $\mathrm{PtCu}$ alloy to exhibited remarkable catalytic stability by RiveraLugo Y et al. ${ }^{70}$ Some of the researchers focusing on Palladium ${ }^{71}$ and 
Platinum alloy or core/shell structures like as tree shape. Xiong $X$ et al., ${ }^{72}$ is one of the group that focus on the Pd/Pt structures. Their results showed that the dendrite structures significantly give higher advantages compare to nanoparticle $\mathrm{Pt} / \mathrm{C}$ catalysts. It reduced the mass transport and ohmic polarization in membrane at PEM Fuel Cells. The last but not least, Gutsche $\mathrm{C}$ et al., ${ }^{73}$ used $\mathrm{Pt}$ as a core material and coated by Iridium material. These structures improved the stability in cyclic voltammetry in comparison to Pt nanorods. We are persuaded that the metallic GLAD nanorods that are made up of low-cost-metal bases prove durable, thermally stable, and adhesively strong to Pt. Conformally coating these nanorods with a thin layer of Pt can further facilitate ORR electrocatalytic activity; this procedure would reduce the Pt needed so that commercialization of PEM fuel cells would be more feasible. The conformal shell coating of the Pt catalyst later is vital so as not to expose the non-Pt metal base support to the electrochemical fuel cell environment. Exposure of the base core would introduce corrosion effects detrimental to the stability of the Pt catalysts.

\section{Conclusion}

This paper reviewed combined some of the SAD and GLAD approaches. This was accomplished by fabricating GLAD Ni or WC nanorod supports and then conformally coating the supports with a SAD Pt thin layer shell. The SAD Pt shell provided a potential electrocatalyst of ORR. Research showed that the Ni@WC nanorods from GLAD usually result in irregular crystal orientation possible of growing nanorods with crystal planes that electrochemically facilitate ORR better than the conventional polycrystalline nanoparticles' and thin-film method. Using non-Pt-metallic nanorod cores comprised of less-expensive metals such as $\mathrm{Ni}, \mathrm{Cr}$, and $\mathrm{WC}$ reduced $\mathrm{Pt}$ loading to more cost-effective values; coating these metallic cores with $\mathrm{Pt}$ maintained - and even enhanced - the electrochemical activity during ORR. This paper proposed differing the roughness of substrates will lead to nanorods of varying dimensions expanding possible electrochemical properties.

\section{Acknowledgements}

None.

\section{Conflict of interest}

Author declares there is no conflict of interest.

\section{References}

1. Ulrich L. Hydrogen Fuel Cell Cars Return for another Run. 2015.

2. Slav I. What Could Push Oil to 100\$? 2018.

3. Overview of Greenhouse Gases. United States Environmental Protection Agency.

4. http://americanhistory.si.edu/fuelcells/origins/origins.htmv

5. http://www.innovateus.net/invention/hydrogen-fuel-cell

6. http://www.fuelcelltoday.com/history

7. https://www.hyundaiusa.com/tucsonfuelcell/index.aspx

8. https://ssl.toyota.com/mirai/fcv.html

9. http://world.honda.com/FuelCell/
10. Crabtree GW, Dresselhaus MS. The hydrogen Fuel Alternative. MRS Bulletin. 2008;33(4):421-427.

11. Jakob Kibsgaard, Yelena Gorlin, Zhebo Chen, et al. Meso-Structured Platinum Thin films: Active abd Stable electrocatalysts for the Oxygen Reduction Reaction. J Am Chem Soc. 2012;134(18):7758-7765.

12. Allan R. Mems: A New Power Source Forportables. Electronic Design. 2005;53:43-47.

13. Looking for Fuel Cells 2000?

14. Bechtold RL. Alternative Fuels Guide book. Society of Automotive Engineers. 1997. p. 214.

15. Lashway RW. Fuel Cells: The Next Evolution. MRS Bulletin. 2005;30(8):581-583.

16. Harris S. The Fuel Cell Review. 2004. 31 p.

17. Wang Y, Chen KS, Mishler J, et al. A review of polymer electrolyte membrane fuel cells: Technology, application, and needs on fundamental research. Applied Energy. 2011;88(4):981-1007.

18. McWay G. US. Dept. of Energy Report on Solid State Conversersion Alliance (SECA). US Dep of Energy. 1999.

19. Doyle M, Rajendran G. Perfluorinated membranes. In: Vielstich W, Gasteiger HA, editors. Handbook of Fuel Cells: Fundamentals, Technology, and Application. Wiley \& Sons. 2003. 351 p.

20. Hilbert K. Handbook of Fuel Cells, Fundamentals, Technology and Application. Wiley \& Sons. 2003. 1037 p.

21. Bagotsky VS. Fundamentals of Electrochemistry. 2nd ed. Wiley \& Sons. 2005. p. 361-363.

22. http://www.isondopm.com/wp-content/uploads/2016/01

23. Wee JH, Lee KY, Kim SH, et al. Fabrication methods for low-Pt loading electrocatalysts in proton exchange membrane fuel cell systems. Journal of Power Sources. 2007;165(2):667-677.

24. National Research Council. Review of the Research Program of the Freedom Car and Fuel Cell partnership. First Report, National Academic Press. 2005.

25. Norbeck JM, Heffel JW, Durbin TD, et al. Hydrogen Fuel for Surface Transportation. Society of Automotive Engineers. 1996. 566 p.

26. International Energy Agency. Hydrogen \&Fuel Cells: Review of National R\&D Program. Organization for Economic Co-Operation and Development. 2004;2004:i-208(208).

27. Crabtree GW, Dresselhaus MS. The Hydrogen Fuel Alternative. MRS Bulletin. 2008;33(4):421-427.

28. Ludlow DJ, Calebrese CM, Yu SH, et al. PEM Fuel Cell membrane hydration measurement by neutron imaging. J Power Sources. 2006;162(1):271-278.

29. Salomov UR. Pro-scale modeling of fluid flow through gas diffusion and catalyst layers for high temperature proton exchange membrane (HTPEM) fuel cells. Comp and Math with Applications. 2014;67:393-411.

30. Ogumi Z. Polymer Electrolyte Fuel Cells(PEFCs)-State of the Art. Technical report. Kyoto University; 2004:30-35.

31. Berning T, Lu DM, Djilali N, et al. Three-dimensional computational analysis of transport phenomena in PEM fuel cells. Journal of Power Sources. 1997;106(2):83-88.

32. Litster S. PEM fuel cell electrodes. Journal of Power Sources. 2004;130(2):61-76. 
33. Haile SM. Fuel Cell materials and components. Acta Materialia. 2003;51:5981-6000.

34. Ward CA, Garcia JA. Analytical method for determining the internal resistance and electrocatalyst utilization of fuel cell. Journal of Power Sources. 1997;66(2):83-88.

35. Basic Research Needs for the Hydrogen Economy. Report of the DOE Basic Energy Sciences Workshop on Hydrogen Production, Storage and Use. 2003.

36. Mark K Debea, Alison Schmoeckela, Susan Hendricksa, et al. Durability Aspects of Nanostructured Thinfilm Catalyst for PEM Fuel Cells. ECS Transactions. 2006;1(8):51-66.

37. Levi BG. Physics Today. 2009. p. 16

38. Beck KN. PhD Thesis, Swiss Federal Institute of Technology, Zurich; 2006

39. Markovic NM, Gasteiger HA. Oxygen Reduction on Platinum LowIndex Single-Crystal Surfaces in Sulfuric Acid Solution: Rotating RingPt(hkl) Disk Studies. The Journal of Physical Chemistry. 1995;99(11): 3411-3415.

40. Markovic N, Gasteiger H, Ross PN, et al. Kinetics of Oxygen Reduction on Pt(hkl) Electrodes: Implications for the Crystallite Size Effect with Supported Pt Electrocatalysts. J Electrcochem Soc. 1997;144(5):15911597.

41. Markovic NM, Adzic RR, Cahan BD, et al. ISE Proceedings. Montreaux. 1991. $138 \mathrm{p}$.

42. Satyapal S. Hydrogen program overview. Annual Merit Review Proceedings. 2009.

43. Goodwin JG. Effects of impurities on fuel cell performance and durability. 2009 annual Merit Review Proceedings. 2009.

44. Tang H, Qi Z, Ramani M, et al. PEM fuel cell cathode carbon corrosion due to the formation of air/fuel boundary at the anode. J Power Sources. 2006;158(2):1306-1312.

45. Khudhayer WJ. Nanostructured Catalyst Materials for Next Generation Polymer Electrolyte Membrane (PEM) Fuel Cells. ProQuest Dissertations and Theses. 2011;73(4): 168.

46. Gasteiger HA, Kocha SS, Somappli B. et al. Activity Benchmarks and Requirements for Pt, Pt-Alloy, and Non-Pt Oxygen Reduction Catalysts for PEMFCs. Applied Catalysis B: Environmental. 2005;56(1):9-35.

47. Mallouk TE, Smotkin ES. Combinatorial catalyst development methods. Handbook of Fuel Cells-Fundamentals, Technology and Application. Wiley \& Sons. 2003;2(3):334-347.

48. Nancy Kariuki, Fatma Yurtsever, Mahbuba Begum, et al. Glad-SAD Pt-Ni Alloy/Ni Nanorods as Highly Active Oxygen Reduction Reaction Electrocatalyst. The Electrochemical Society. 2015;26:1556.

49. Yurukcu M, Cansizoglu H, Cansizoglu MF, et al. Conformality of PVD shell layers on vertical arrays of rods with different aspect ratios investigated by Monte Carlo Simulations. MRS Advances. 2017;2(8):465-470

50. Mahbuba Begum, Mesut Yurukcu, Fatma Yurtsever, et al. Pt-Ni/WC Alloy nanorods Arrays as ORR Catalyst for PEM Fuel Cells. ECS Transactions. 2017;80(8):919-925.

51. Wisam J Khudhayer, Mahbuba Begum, Udaya B Nasini, et al. Oxygen reduction reaction electrocatalytic activity of tilted pt nanorod arrays fabricated by glancing angle deposition. $J$ of Applied Electrochemistry. 2015;45(10):1113-1121.
52. Kariuki NN, Cansizoglu MF, Begum M, et al. SAD-GLAD Pt-Ni@ Ni nanorods as highly active oxygen reduction reaction electrocatalysts. ACS Catalysis. 2016;6(6):3478-3485.

53. Cansizoglu H, Yurukcu M, Cansizoglu MF, et al. Investigation of physical vapor deposition techniques of conformal shell coating for core/shell structures by Monte Carlo Simulations. Thin Solid Films. 2015;583:122-128.

54. Wang Q, Eikerling M, Song D, et al. Structure and performance of different types of agglomerates in cathode catalyst layers of PEM fuel cells. J Electroanalytical Chemistry. 2004;573(1):61-69.

55. Wisam J Khudhayer, Nancy Kariuki, Deborah J Myers, et al. GLAD Cr nanorods coated with SAD Pt thin film for oxygen reduction reaction. $J$ Electrochemical Society. 2012;159(6):B729-B736.

56. https://energy.gov/eere/fuelcells/doe-technical-targets-polymerelectrolyte-membrane-fuel-cell-components

57. Lassner E, Schubert WD. Tungsten: Properties, Chemistry, Technology of the element, Alloys, and Chemical Compounds. Kluwer Academic/ Plenum Publishers. 1999. 369 p.

58. Harnisch F, Schroder U, Quaas M, et al. Electrocatalytic and corrosion behavior of tungsten carbide in near neutral $\mathrm{Ph}$ electrolytes. Applied Catalysis B: Environmental. 2009;87(2):63-69.

59. Nie M, Shen PK, Wu M, et al. A study of oxygen reduction on improved Pt-WC/C electrocatalysts. J of Power Sources. 2006;162(1):173-176.

60. Santos L, Freitas KS, Ticianelli EA, et al. Electrocatalysis of oxygen reduction and hydrogen oxidation in platinum dispersed on tungsten carbide in acid medium. $J$ of Solid State Electrochemistry. 2007;11(11):1541-1548.

61. Wang Y, Song S, Maragou V, et al. High surface area tungsten carbide microspheres as effective Pt catalyst support for oxygen reduction reaction. Applied Catalysis B-Environmental. 2009;89(2):223-228.

62. Karabacak T, Singh JP, Zhao YP, et al. Scaling during shadowing growth of isolated nanocolumns. Physical Review B. 2003.

63. Khudhayer WJ, Kariuki NN, Wang X, et al. Oxygen reduction reaction electrocatalytic activity of glancing angle deposition platinum nanorod arrays. J of the Electrochemical Society. 2011;158(8):1029-1041.

64. Kariuki NN, Khudhayer WJ, Karabacak T, et al. GLAD Pt-Ni alloy nanorods for oxygen reduction reaction. ACS Catalysis. 2013;3(12):3123-3132.

65. Kim S, Karabacak T, Lu TM, et al. Hydrogen generation using ruthenium nano-rod array electrodes. Smarts and Materials. 2006.

66. Takimoto D, Ohnishi T, Nutariya J, et al. Ru-core@Pt-shell nanosheet for fuel cell electrocatalyss with high activity and durability. Journal of Catalysis. 2017;355:185.

67. Jiang R, Zhang J. A review of core-shell nanostructured electrocatalysts for oxygen reduction reaction. $J$ Ensm. 2017.

68. Yang L, Banham D, Markiewichz M, et al. The Electrochemical Society. 2018. 2170 p.

69. Dhanasekaran P, Bhai SD. Boosting Pt oxygen reduction reaction activity and durability by carbon semi-coated titania nanorods for proton exchange membrane fuel cells. Electrochimica Acta. 2018;263:596-609.

70. Rivera-Lugo Y, Felix-Navarro MF. Effect of template, reaction time and platinum concentration in the synthesis of $\mathrm{PtCu} / \mathrm{CNT}$ catalyst for PEMFC applications. Energy. 2018;148:561-570. 
71. Am DJ. Palladium-nickel alloys loaded on tungsten carbide as platinumfree anode electrocatalysts for polymer electrolyte membrane fuel cells Chem Commun. 2011;47(20):5792-5794.

72. Xiong $\mathrm{X}$, Chen S. Pt-Pd nanodendrites as oxygen reduction catalyst in polymer-electrolyte-membrane fuel cell. J Ijhydene. 2017;42(40):25234-25243.
73. Gutsche C, Moeller JC, Knipper M, et al. Synthesis, Structure, and Electrochemical Stability of Ir-Decorated RuO2 Nanoparticles and Pt Nanorods as Oxygen Catalysts. J Phys Chem C. 2016;120(2):11371146. 